doi: 10.17492/focus.v2i2.8620

\title{
How do Foreign Direct Investment and Growth Interact in India?
}

\author{
Gurmeet Singh*
}

\begin{abstract}
The study investigates the relationships between the FDI and economic growth, namely, Gross Domestic Product, exports and foreign exchange reserves over the period 1994 to 2013. Johansen's co-integration and vector error correction model have been applied to explore the long-run equilibrium relationship between foreign direct investment and economic growth. The analysis reveals that economic growth and the foreign direct investment are co-integrated and, hence, a long-run equilibrium relationship exists between them. It is observed that the foreign direct investment is positively related to gross domestic product and foreign exchange reserves but negatively related to exports. Exports are found to be insignificant in determining FDI. In the Granger causality sense, FDI causes GDP in both long run and short-run. No bidirectional causality is observed between any variables under study. Furthermore, the findings of VECM and Granger Causality test show that FDI creates a long run relationship with economic growth but in short run no causality is found between FDI, exports and foreign exchange reserves.
\end{abstract}

Keywords: Foreign Direct Investment, GDP, Causality Test, Co-integration Test.

\subsection{Introduction}

Foreign direct investment (FDI) has always been an issue of importance for the developing economies such as India. The world has been globalising and all the countries are liberalising their policies for welcoming investment from countries which are abundant in capital resources. The countries which are developed are focusing on new markets where there is availability of abundant labour, large market to sell their products, and where high profits can be achieved. The objective behind allowing FDI is to complement and supplement domestic investment, for achieving a higher level of economic development and providing opportunities for technological up gradation, as well as access to global managerial skills and practices.

*Assistant Professor, Unitedworld School of Business, Gandhinagar, Gujarat. 
2 |FOCUS: Journal of International Business, Volume 2, Issue 2

FDI refers to an investment directly into production in a country by a company located in another country, either by buying a company in target country or by expanding operations of an existing business in that country. FDI in India has played an important role in the development of the Indian economy during the recession. FDI in India has in a lot of ways - enabled India to achieve a certain degree of financial stability, growth and development. This money has allowed India to focus on the areas that may have needed economic attention and address various problems that continue to challenge the country. The factors that attracted investment in India are stable economic policies, availability of cheap and quality human resources, and opportunities of new unexplored markets. Mostly FDI are flowing in service sector and manufacturing sector recorded very low investments. The investments in service sector will enhance the benefit of flow of funds to the home country. Romer (1986) and Sala-i-Martin (1996) claim that FDI brings technology to the target country as well.

FDI has helped India to attain financial stability and economic growth with the help of investments in different sectors. FDI has boosted the economic life of India and on the other hand there are critics who have blamed the government for ousting the domestic inflows. After liberalisation of trade policies in India, there has been a positive GDP growth rate in Indian economy. Foreign direct investments helps in developing the economy by generating employment for the unemployed, generating revenues in the form of tax and incomes, financial stability to the government, development of infrastructure, backward and forward linkages to the domestic firms for the requirements of raw materials, tools, business infrastructure, and support for financial system. Forward and back ward linkages are developed to support the foreign firms with supply of raw and other requirements. It helps in generation of employment and also helps poverty eradication. There are many businesses or individuals who would earn their livelihood through the foreign investments. There are legal and financial consultants who also guide in the early stage of establishment of firm. The presence of unique ownership advantages (O-advantages), attractive location factors of host country (L-advantages) and competitive advantages of a firm (I-advantages) acts as a precondition for a company to invest abroad. (Dunning, 1993). Roy and van der Berg (2006) claim that the lack of sufficient data is the main reason behind the mixed results.

Among the many macroeconomic variables, three variables are selected based on their theoretical importance, performance measures of the economy, and also their uses and findings in the previous empirical literature. Based on the above discussion, the present study tries to investigate the long run and short run relationship between the FDI and three macroeconomic variables, by considering the following model:

$$
\mathrm{Xt}=(\text { FDIt, GDPt, EXPORTt, FRt, })
$$


where, FDI is foreign direct investment, GDP is gross domestic product, FR is foreign exchange reserves and $\mathrm{X}$ is a $4 \times 1$ vector of variables.

\subsection{Literature Review}

Dunning (1993) describes three main types of FDI based on the motive behind the investment from the perspective of the investing firm. The first type of FDI is called market-seeking FDI, whose aim is to serve local and regional markets. It is also called horizontal FDI, as it involves replication of production facilities in the host country. A second type of FDI is called resource-seeking, when firms invest abroad to obtain resources not available in the home country, such as natural resources, raw materials, or low-cost labour. The third type of FDI, called efficiency-seeking, takes place when the firm can gain from the common governance of geographically dispersed activities in the presence of economies of scale and scope.

Inflow of FDI and GDP are positively related. Economic indicators have more powerful effect on FDI than political indicators. Although, the effect of political ideology of a country has an impact on inflow of FDI in that country, it can also affect the level of protection to local industries (Levis, 1979). Countries with high per capita GDP are main source of attraction for inflow of FDI (Schneider \& Frey, 1985). Inflow of FDI in any country is also affected by macro-economic performance of that country (Santiago, 1987). Inflow of FDI can negatively affect the saving level and balance of payment position in the host country, while it can also improve the current account position of the host country (Fry, 1993). Level of transparency in policies and institutions of a country has its impact on inflow of FDI in that country. Higher level of transparency results in higher level of FDI inflow. Thus, there is positive relationship between transparency and FDI (Drabek \& Payne, 1999). It is also evident that FDI also becomes the cause of poverty reduction in the developing countries through increase in the level of economic growth in those countries. Growth plays its key role in reduction of poverty and importance of FDI for enhancement of growth level is also very clear (Klein, Aaron, \& Hadjimichael, 2001). Population size of the host country and its cheap labor force also becomes the sources of inspiration for the foreign investors and a country like china has better bargaining power while bidding for FDI (Braunstein \& Epstein, 2002). Structural factors like stage of value adding, nationality, size of firm and entry mode are focused by the determinants of desirability of FDI (Enderwick, 2005). Determinants of change in FDI policy in developing and transitional countries are also studied by (Kobrinm \& Xun, 2005). They found that if liberalization is in the national interest, it will be a rational decision. Competition which emulates from actions taken by 
4 | FOCUS: Journal of International Business, Volume 2, Issue 2

countries are regarded as peer, coerced adoption of neoliberal economic policies as a result of the impact of changes in domestic, political and economic factors. Improvement of location factors is also very important in order to attract FDI in any country.

Earlier studies examining the relationship between FDI and growth postulated a negative association for developing countries (Singer, 1950) (Griffin, 1970). The logic of these studies was that FDI was concentrated on low-priced primary exports to developed countries, and had a negative impact on overall growth. However studies by (RosensteinRodan, 1961) and (Chenery \& Strout, 1966) showed that FDI had a favorable impact on productivity and growth in developing countries. Further, (Barro \& Sala-I-Martin, 1995) and (Grossman \& Helpman, 1995) argue that FDI has long term positive impact by generating increasing returns through technology and knowledge transfers.

At the macro level, by and large, the previous literature finds a positive impact of FDI, but the impact varies from country to country and depending on country conditions. Blomstrom et al., (1994) find that FDI has a positive impact on growth in rich countries. Further Borensztein et al., (1998) argued that FDI inflows are positively related to per capita GDP growth provided the host country has a highly educated workforce. Alfaro et al., (2000) find that FDI positively affects growth in sufficiently developed markets. Similarly Balsubramanyam et al., (1996) emphasise trade reforms to create a positive impact of FDI on growth. Based on a disaggregate analysis, Wang (2002) finds that FDI in manufacturing has a significant positive impact on growth. Bende-Nebende and Ford (1998) find that the output of less developed countries responds more positively to FDI. Borensztein et al., (1998) explains that because of the transfer of technology, FDI contributes more to growth than domestic investment.

Investment policy reviews by UNCTAD provide evidence of benefits of FDI in terms of employment generation, wages, and linkages with local firms, increases in technology intensive exports, range of new products and services, etc. Overall, UNCTAD investment reviews suggest that FDI has a positive impact on growth but that it varies from country to country (UNCTAD, 2003). By and large, previous literature suggests that FDI contributes to growth through capital formation and technology transfer (Blomstrom et al., (1994) and Borensztein et al., (1996) along with accumulation of knowledge due to labor training and skill acquisition (DeMello, 1999). Therefore, the most frequently cited common benefits of FDI are productivity spillovers for the host economy, resulting in higher growth. The logic is that FDI provides a stock of knowledge capital to less developed or developing economies and make factors of production, namely labor and capital, more productive. Thus, most of the previous studies show a positive impact of FDI on the host country economy (DeMello, 1999) (Bende-Nabende \& Ford, 1998) (Durham, 2004) (Nair-Reichert \& Weinhold, 2001) (Xu, 
2000). However, the impact varies from country to country (UNCTAD, 2003) (Braunstein \& Epstein, 2002) (Bende-Nabende \& Ford, 1998). Further, a positive impact effect of FDI on improving growth and per capita growth is found in studies such as (Caves, 1974) (Lipsey, 1999) (Grossman \& Helpman, 1995) (Blomstrom, Lipsey, \& Zegan, 1994).

There are many past studies which have emphasized the role of GDP growth, wage rate, trade rate, real interest rates, inflation, and stock of FDI, domestic investment in attracting FDI into a country. Camurdan \& Ismail (2009) developed an empirical framework to estimate the economic determinants of FDI inflows by employing a panel data set of 17 developing countries and transition economies for the period of 19892006. Seven independent variables are taken for this research namely, the previous period FDI, GDP growth, wage, trade rate, the real interest rates, inflation rate, and domestic investment. The results conclude that the previous period FDI is important as an economic determinant. Besides, it is also understood that the main determinants of FDI inflows are the inflation rate, the interest rate, the growth rate and the trade (openness) rate.

Hosein et al., (2009) investigate the causal relationships between foreign direct investment (FDI), domestic investment (DI) and economic growth (GDP) in Egyptian, Moroccan and Tunisian economies. This paper applies a co-integration time series techniques; vector error correction (VEC) model over the sample period for the period from1970 to 2006. They find a unidirectional causality between FDI and GDP in Egypt and Morocco, and bi-directional causality between FDI and GDP in Tunisia. Domestic investment has played a great role for driving FDI into these countries more than GDP. The study also shows that FDI is more effective than DI for promoting growth.

A study by (Marr, 1997) reviews the recent evidence on the scale of FDI to lowincome countries over the period 1970- 96 and major factors determining foreign companies' decisions to invest in a particular country. The paper concludes that large market size, low labour costs and high returns in natural resources are amongst the major determinants in the decision to invest in these countries. China, as a major emerging market, has attracted significant flows of FDI, to become the second largest receipt. Shaukat \& Guo (2005) briefly examine the literature on FDI and focuses on likely determinants of FDI in China. They analyse responses from 22 firms operating in China on what they see as the important motivations for them to undertake FDI. Results show that market size (in terms of GDP) is a major factor for FDI especially for the United States firms. For local, export-oriented, Asian firms, low labour cost is the main factor. Coming to the research focusing on FDI-Growth relation in India, papers concentrating solely on India are only a few. Much empirical testing has been done so far on 
6 | FOCUS: Journal of International Business, Volume 2, Issue 2

macroeconomic variables and FDI for monthly and quarterly data but to the best of our knowledge not much empirical testing has been done on yearly data.

\subsection{Data and Methodology}

The aim of this paper is to investigate the relationship between the foreign direct investment and growth, namely, gross domestic product, exports and foreign exchange reserve. To accomplish the research objective, yearly data ranging from 1994 to 2013 are obtained which comprises 20 data points for the analysis. The choice of study period is based on the availability of data series. Descriptions of variables and data sources are presented in Table 1. All variables are converted into natural logarithmic form.

Table 1: Description of Variables

\begin{tabular}{|l|l|l|}
\hline Acronyms & \multicolumn{1}{|c|}{ Construction of Variable } & \multicolumn{1}{c|}{ Data Source } \\
\hline FDI & Natural Logarithm of the Foreign Direct Investment & World Bank Website \\
\hline GDP & Natural Logarithm of the Gross Domestic Product & RBI Website \\
\hline Export & Natural Logarithm of the Export & RBI Website \\
\hline FR & Natural Logarithm of the Foreign Exchange Reserve & RBI Website \\
\hline
\end{tabular}

The present study employs the time series data analysis technique to study the relationship between the FDI and growth. In a time series analysis, the results might provide a spurious if the data series are non-stationary. Thus, the data series must follow the time series properties i.e. the time series data should be stationary, meaning that, the mean and variance should be constant over time and the value of covariance between two time periods depends only on the distance between the two time period and not the actual time at which the covariance is computed. The most popular and widely used test for stationary is the unit root test. The presence of unit root indicates that the data series is non-stationary. The standard procedures of unit root test namely the Augmented Dickey Fuller (ADF) (1979) (1981) is performed to check the stationary nature of the series. Assuming that the series follows an AR (p) process the ADF test makes a parametric correction and controls for the higher order correlation by adding the lagged difference terms of the dependent variable to the right hand side of the regression equation. In the ADF test null hypothesis is that data set being tested has unit root. This provides a robustness check for stationary. The unit root tests also provide the order of integration of the time series variables. In a multivariate context if the variable under 
consideration are found to be I (1) (i.e. they are non-stationary at level but stationary at first difference), but the linear combination of the integrated variables is I (0), then the variables are said to be co-integrated (Enders, 2004). The Augmented Dickey Fuller (ADF) $(1979 ; 1981)$ is performed to check the stationary nature of the series. The complete model with deterministic terms such as intercepts and trends is shown in equation (1).

$\Delta y_{t}=\alpha+\beta t+\gamma y_{t-1}+\delta_{1} \Delta y_{t-1}+\cdots+\delta_{p-1} \Delta y_{t-p+1}+\varepsilon_{t}$,

where $\alpha$ is a constant, $\beta$ is the coefficient on a time trend and $p$ is the lag order of the autoregressive process. Lag length for VAR system is, selected based on minimum sequential modified LR test statistic (each test at 5\% level) (LR), Final Prediction Error (FPE), Akaike Information Criterion (AIC), Schwarz Information Criterion (SC) and Hannan-Quinn Information Criterion (HQ). The estimation of co-integration using this method, involves estimation of following unrestricted VAR model:

$$
Y_{t}=A_{0}+\sum_{i-1}^{n} A_{i} Y_{t-1}+\epsilon_{t}
$$

where: $Y_{t}$ is $n \times 1$ vector of non-stationary $\mathrm{I}(1)$ variables, Ao is an $n \times 1$ vector of constants, $n$ is no of lags. A $i$ is an $\mathrm{n} \times \mathrm{n}$ matrix of estimated parameters. $E t$ is $\mathrm{n} \times 1$ vector independent error term.

With the non-stationary series, co-integration analysis has been used to examine whether there is any long run relationship exists. However, a necessary condition for the use of co-integration technique is that the variable under consideration must be integrated in the same order and the linear combinations of the integrated variables are free from unit root. According to Engel and Granger (1987), if the variables are found to be co-integrated, they would not drift apart over time and the long run combination amongst the non-stationary variables can be established. To conduct the co-integration test, the Engel and Granger (1987) or the Johansen and Juselius (1990) or the Johansen (1991) approach can be used. The Engel-Granger two step approaches can only deal with one linear combination of variables that is stationary. In a multivariate practice, however, more than one stable linear combination may exist. The Johansen's co-integration method is regarded as full information maximum likelihood method that allows for testing co-integration in a whole system of equations.

The Johansen methods of co-integration can be written as the following vector autoregressive framework of order $\mathrm{p}$.

$$
X_{t}=A_{0}+B_{j} X_{t-j}+e_{t}
$$

where, $X_{t}$ is an $n \times 1$ vector of non-stationary $I(1)$ variables, $A_{0}$ is an $n \times 1$ vector of constants, $p$ is the maximum lag length, $B j$ is an $n \times n$ matrix of coefficient and et is a $n \times 1$ 
8 | FOCUS: Journal of International Business, Volume 2, Issue 2

vector of white noise terms. The number of characteristic roots can be tested by considering the following trace statistic and the maximum eigenvalue test.

$$
\begin{aligned}
& \lambda_{\text {trace }}(r)=-T \sum_{i=j+1}^{p} \ln \left(1-\hat{\lambda}_{j}\right) \\
& \lambda_{\text {max }}(r, r+1)=-T \ln \left(1-\hat{\lambda}_{r+1}\right)
\end{aligned}
$$

where, $r$ is the number of co-integrating vectors under the null hypothesis, $\mathrm{T}$ is the number of usable observations and $\hat{\lambda}_{j}$ is the estimated value for the $\mathrm{j}^{\text {th }}$ ordered characteristic roots or the eigenvalue from the $\Pi$ matrix.

A significantly non-zero eigenvalue indicates a significant co-integrating vector. The trace statistics is a joint test where the null hypothesis is that the number of cointegration vectors is less than or equal to $r$ against an unspecified general alternative that there are more than $r$. Whereas, the maximum eigenvalue statistics test the null hypothesis that the number of co-integrating vectors is less than or equal to $r$ against the alternative of $\mathrm{r}+1$ (Enders, 2004) (Brooks, 2002). The presence of co-integrating vectors supports the application of a dynamic VECM that depicts the feedback process and speed of adjustment for short run deviation towards the long run equilibrium and reveals short run dynamics in any variables relative to others.

To use the Johansen's method, equation (3) needs to be turned into a vector error correction model (VECM) which can be written as

$$
\Delta X_{t}=A_{0}+\sum_{j=1}^{p-1} r_{j}+\pi X_{t-p}+e_{t}
$$

where, $\Delta$ is the first difference operator, $r_{j}=\sum_{i=j+1}^{p} B_{j}$ and $\mathrm{n}=-1+\sum_{i=j+1}^{p} B_{j}$ and $I$ is an $\mathrm{n} \times \mathrm{n}$ identity matrix.

The test for co-integration between the X's is calculated by observing the rank of the $\mathrm{P}$ matrix via its eigenvalues. The rank of a matrix is equal to the number of its characteristic roots that are different from zero. The hypothesis is H0: $\pi=\alpha \beta^{\prime}$ where $\alpha$ and $\beta$ are $\mathrm{n} \times \mathrm{r}$ loading matrices of eigenvectors. The matrix $\beta$ gives the co-integration vectors, while $\alpha$ is known as the adjustment parameters that gives the amount of each cointegration entering each equation of the VECM. The aim is to test the number of $\mathrm{r}$ cointegrating vectors such as $\beta 1, \beta 2, \ldots \ldots \beta$.

At the end, the Granger Causality test (Engel \& Granger, 1987) has been used to find out the direction of causality between the variables. To test for Granger Causality, the following bi-variate regression model can be used:

$$
\begin{aligned}
& y_{t}=\alpha_{0}+\sum_{i=1}^{m} \alpha_{i} Y_{t-i}+\sum_{j=1}^{n} \beta_{j} X_{t-1}+\varepsilon_{t} \\
& x_{t}=\omega_{0}+\sum_{i=1}^{m} \gamma_{i} Y_{t-i}+\sum_{j=1}^{n} \theta_{j} X_{t-1}+\varepsilon_{t}
\end{aligned}
$$


If all the coefficients of $x$ in the first regression equation of $y$, i.e. $\beta i$ for $i=1 \ldots . .1$ are significant, then the null hypothesis that $\mathrm{x}$ does not cause $\mathrm{y}$ is rejected.

\subsection{Empirical Analysis}

The descriptive statistics for all the variables under study, namely, FDI and GDP, Export, Foreign Exchange Reserve are presented in Table 2. The value of skewness and kurtosis indicate the lack of symmetric in the distribution. Generally, if the value of skewness and kurtosis are 0 and 3 respectively, the observed distribution is said to be normally distributed. Furthermore, if the skewness coefficient is in excess of unity it is considered fairly extreme and the low (high) kurtosis value indicates extreme platykurtic (extreme leptokurtic). From Table 2, it is observed that the frequency distributions of underlying variables are normal. The significant coefficient of JarqueBera statistics also indicates that the frequency distributions of considered series are normally distributed. The value of standard deviation indicates that foreign direct investment, export and foreign exchange reserve are relatively more volatile as compare to gross domestic product.

Table 2: Descriptive Statistics of Variables

\begin{tabular}{|c|c|c|c|c|}
\hline & LNFDI & LNGDP & LNEXPORT & LNFR \\
\hline Mean & 22.79996 & 10.2511 & 8.050448 & 8.328717 \\
\hline Median & 22.46342 & 10.19294 & 7.914198 & 8.553741 \\
\hline Maximum & 24.49387 & 10.91183 & 9.701567 & 9.808633 \\
\hline Minimum & 20.69617 & 9.630591 & 6.547517 & 6.600034 \\
\hline Std. Dev. & 1.179776 & 0.404773 & 0.979826 & 1.143241 \\
\hline Skewness & 0.033358 & 0.161619 & 0.191524 & -0.201451 \\
\hline Kurtosis & 1.63985 & 1.803857 & 1.806987 & 1.53144 \\
\hline Jarque-Bera & 1.545383 & 1.279369 & 1.308339 & 1.932499 \\
\hline Probability & 0.461769 & 0.527459 & 0.519874 & 0.380507 \\
\hline Sum & 455.9993 & 205.0219 & 161.009 & 166.5743 \\
\hline Sum Sq. Dev. & 26.445580 & 3.112981 & 18.241100 & 24.833020 \\
\hline Observations & 20 & 20 & 20 & 20 \\
\hline
\end{tabular}

Source: Author's Estimation 
10 | FOCUS: Journal of International Business, Volume 2, Issue 2

To check the stationarity of the underlying data series, we follow the standard procedure of unit root testing by employing the Augmented Dickey Fuller (ADF) test. The results are presented in Table 3. On the basis of the ADF test, all the series are found to be non-stationary at level with intercept. However, after taking the first difference these series are found to be stationary at 1,5 and 10 percent level except GDP and foreign Exchange reserve. The stationary test indicates that the series are individually integrated of the order I (1).

Table 3: Result of Augmented Dickey-Fuller Unit Root Test

\begin{tabular}{|c|c|c|c|c|c|c|c|c|}
\hline \multirow{2}{*}{ Variable } & & & \multicolumn{2}{|c|}{ Trend } & \multicolumn{2}{|c|}{ Trend \& Intercept } & \multicolumn{2}{|c|}{ None } \\
\hline & & & t-Stat. & Prob.* & t-Stat. & Prob.* & $\mathrm{t}$-Stat. & Prob.* \\
\hline \multirow{4}{*}{ D(LNFDI) } & \multicolumn{2}{|c|}{$\begin{array}{l}\text { Augmented Dickey- } \\
\text { Fuller test statistic }\end{array}$} & -4.3059 & 0.0040 & -4.1420 & 0.0221 & -3.955 & 0.0005 \\
\hline & \multirow{3}{*}{$\begin{array}{l}\text { Test } \\
\text { critical } \\
\text { values: }\end{array}$} & $1 \%$ level & -3.8574 & & -4.5716 & & -2.6998 & \\
\hline & & $5 \%$ level & -3.0404 & & -3.6908 & & -1.9614 & \\
\hline & & $10 \%$ level & -2.6606 & & -3.2869 & & -1.6066 & \\
\hline \multirow{4}{*}{ D(LNGDP) } & \multicolumn{2}{|c|}{$\begin{array}{l}\text { Augmented Dickey- } \\
\text { Fuller test statistic }\end{array}$} & -2.7898 & 0.0794 & -2.6700 & 0.2580 & -0.7600 & 0.3728 \\
\hline & \multirow{3}{*}{$\begin{array}{l}\text { Test } \\
\text { critical } \\
\text { values: }\end{array}$} & $1 \%$ level & -3.8574 & & -4.5716 & & -2.6998 & \\
\hline & & $5 \%$ level & -3.0404 & & -3.6908 & & -1.9614 & \\
\hline & & $10 \%$ level & -2.6606 & & -3.2869 & & -1.6066 & \\
\hline \multirow{4}{*}{$\begin{array}{l}\text { D(LNEXP } \\
\text { ORT) }\end{array}$} & \multicolumn{2}{|c|}{$\begin{array}{l}\text { Augmented Dickey- } \\
\text { Fuller test statistic }\end{array}$} & -5.4968 & 0.0004 & -5.7136 & 0.0012 & -0.3041 & 0.5600 \\
\hline & \multirow{3}{*}{$\begin{array}{l}\text { Test } \\
\text { critical } \\
\text { values: }\end{array}$} & $1 \%$ level & -3.8574 & & -4.5716 & & -2.7175 & \\
\hline & & $5 \%$ level & -3.0404 & & -3.6908 & & -1.9644 & \\
\hline & & $10 \%$ level & -2.6606 & & -3.2869 & & -1.6056 & \\
\hline \multirow{4}{*}{ D(LNFR) } & \multicolumn{2}{|c|}{$\begin{array}{l}\text { Augmented Dickey- } \\
\text { Fuller test statistic } \\
\end{array}$} & -2.7016 & 0.0930 & -3.0041 & 0.1577 & -1.1082 & 0.2325 \\
\hline & \multirow{3}{*}{$\begin{array}{l}\text { Test } \\
\text { critical } \\
\text { values: }\end{array}$} & $1 \%$ level & -3.8574 & & -4.5716 & & -2.6998 & \\
\hline & & $5 \%$ level & -3.0404 & & -3.6908 & & -1.9614 & \\
\hline & & $10 \%$ level & -2.6606 & & -3.2869 & & -1.6066 & \\
\hline
\end{tabular}

*MacKinnon (1996) one-sided p-values.

Source: Author's Estimation

The presence and the number of co-integrating relationships among the underlying variables are tested through the Johansen procedure i.e., Johansen and Juselius (1990) and Johansen (1991). Specifically, trace statistic and the maximum 
eigenvalue are used to test for the number of co-integrating vectors. The result of VAR lag order selection criteria are presented in the Table 4. Leg order selected for the study is based on LR, FPE, AIC, SC and HQ criterion. The results of both trace statics and the maximum eigenvalue test statistics are presented in Table 5. The trace statistic indicates one co-integrating equations and the maximum eigenvalue statistics also identify one cointegrating equations. The results show that a long-run equilibrium relationship exists between the FDI and GDP, Export and Foreign Exchange Reserve.

Table 4: VAR Lag Order Selection Criteria

\begin{tabular}{|c|c|c|c|c|c|c|}
\hline Lag & LogL & LR & FPE & AIC & SC & HQ \\
\hline 0 & 9.69689 & NA & $6.45 E-06$ & -0.599673 & -0.400843 & -0.566023 \\
\hline 1 & 97.96543 & $\mathbf{1 3 0 . 0 8 0 0}^{*}$ & $\mathbf{3 . 3 7 e - 0 9}^{*}$ & $\mathbf{- 8 . 2 0 6 8 8 7} *$ & $\mathbf{- 7 . 2 1 2 7 4 1}^{*}$ & $\mathbf{- 8 . 0 3 8 6 3 8}^{*}$ \\
\hline
\end{tabular}

* indicates lag order selected by the criterion

LR: sequential modified LR test statistic (each test at 5\% level)

FPE: Final prediction error; AIC: Akaike information criterion; SC: Schwarz information criterion

HQ: Hannan-Quinn information criterion

Source: Author's Estimation

Table 5: Result of Johansen's Co-integration Test

\begin{tabular}{|c|c|c|c|c|c|c|c|}
\hline $\begin{array}{c}\text { Hypothesized } \\
\text { No. of CE(s) }\end{array}$ & Eigenvalue & $\begin{array}{c}\text { Trace } \\
\text { Statistic }\end{array}$ & $\begin{array}{l}0.05 \\
\text { Critical } \\
\text { Value }\end{array}$ & Prob.** & $\begin{array}{c}\text { Max- } \\
\text { Eigen } \\
\text { Statistic }\end{array}$ & $\begin{array}{l}0.05 \\
\text { Critical } \\
\text { Value }\end{array}$ & Prob.** \\
\hline None * & 0.798379 & 54.6211 & 47.8561 & 0.0102 & 28.8246 & 27.58434 & 0.0345 \\
\hline At most 1 & 0.634218 & 25.7965 & 29.7970 & 0.1349 & 18.1029 & 21.13162 & 0.1260 \\
\hline At most 2 & 0.29493 & 7.69359 & 15.4947 & 0.4987 & 6.29025 & 14.2646 & 0.5763 \\
\hline At most 3 & 0.075001 & 1.40333 & 3.84146 & 0.2362 & 1.40333 & 3.841466 & 0.2362 \\
\hline \multicolumn{8}{|c|}{$\begin{array}{l}\text { Max-eigenvalue test indicates } 1 \text { cointegrating eqn(s) at the } 0.05 \text { level } \\
* \text { denotes rejection of the hypothesis at the } 0.05 \text { level } \\
* * \text { MacKinnon-Haug-Michelis (1999) p-values }\end{array}$} \\
\hline
\end{tabular}

Assuming one co-integrating vector, the short run and long run interaction of the underlying variables the VECM has been estimated based on the Johansen co-integration methodology. The results are presented in Table 6. The results show that a long-run equilibrium relationship exists between the foreign direct investment (FDI) and the macroeconomic variables (GDP, export and foreign exchange reserve). The estimated 
12 | FOCUS: Journal of International Business, Volume 2, Issue 2

co-integrating coefficients for the FDI is based on the first normalized eigenvector are as follows. These values represent long term elasticity measures. Thus the co-integration relationship can be re-expressed as:

$\mathrm{FDI}=4.89+(-4.21) * \mathrm{GDP}+5.83 * \mathrm{EXPORT}+(-3.78) * \mathrm{FR}$

Table 6: Results of Vector Error Correction Model

\begin{tabular}{|c|c|c|c|c|}
\hline \multicolumn{5}{|c|}{ Panel A: Normalized Co-integration Coefficients } \\
\hline LNFDI(-1) & LNGDP(-1) & LNEXPORT(-1) & LNFR(-1) & Constant \\
\hline \multirow[t]{3}{*}{1.000000} & -4.205323 & 5.834739 & -3.783182 & 4.890078 \\
\hline & -6.40133 & -2.96044 & -0.63812 & \\
\hline & {$[-0.65695]$} & [ 1.97090] & {$[-5.92860]$} & \\
\hline \multicolumn{5}{|c|}{ Panel B: Coefficient of Error Correction term } \\
\hline & $\mathrm{D}(\mathrm{LNFDI})$ & D(LNGDP) & $\mathrm{D}(\mathrm{LNEXPORT})$ & D(LNFR) \\
\hline & -0.33088 & -0.010650 & -0.032753 & 0.011158 \\
\hline & -0.09745 & -0.00534 & -0.02146 & -0.0293 \\
\hline & {$[-3.39525]$} & [-1.99583] & [-1.52656] & [ 0.38076] \\
\hline F-statistic & 2.434337 & 1.347152 & 2.988167 & 1.694143 \\
\hline
\end{tabular}

Standard errors in ( ) \& t-statistics in [ ]

Source: Author's Estimation

The t-statistics are given in [] brackets while the error term are given in () brackets. The coefficients of GDP and foreign exchange reserve are negative and statistically significant, while the coefficient of Export is positive and statistically insignificant. The intercept term is positive. The results revels that the relationship between FDI and GDP and foreign exchange reserve is positive, while the relationship between the FDI and Export is negative. The sign of the error correction coefficient in determination of FDI is negative (-0.33088) and the t-value is (-3.39525). This indicates that FDI do respond significantly to re-establish the equilibrium relationship once deviation occurs.

The co-integration results indicate that causality exists between the co-integrated variables but it fails to show us the direction of the causal relationship. The pair-wise Granger Causality test (1987) is performed between all possible pairs of variables to determine the direction of causality. The rejected hypotheses are reported in Table 7. The 
results show that the FDI granger causes GDP. While there is no bidirectional causality exists between any variables under study.

Table 7: Result of Granger Causality Test

\begin{tabular}{|l|c|c|c|c|}
\hline Null Hypothesis: & Obs & F-Statistic & Prob. & Decision \\
\hline LNGDP does not Granger Cause LNFDI & 19 & 1.57733 & 0.2272 & Accept \\
\hline LNFDI does not Granger Cause LNGDP & & 0.69422 & 0.4170 & Reject \\
\hline LNEXPORT does not Granger Cause LNFDI & 19 & 1.97543 & 0.1790 & Accept \\
\hline LNFDI does not Granger Cause LNEXPORT & & 0.13373 & 0.7194 & Accept \\
\hline LNFR does not Granger Cause LNFDI & 19 & 4.44448 & 0.0511 & Accept \\
\hline LNFDI does not Granger Cause LNFR & & 0.05183 & 0.8228 & Accept \\
\hline
\end{tabular}

Source: Author's Estimation

\subsection{Conclusion}

This study examined the inter-linkage between the Foreign Direct Investment and macroeconomic variables, namely, gross domestic product, export and foreign exchange reserve using Johansen's co-integration test, VECM and Granger Causality framework. The analysis used yearly data over the period 1994 to 2013 which is obtained from World Bank and RBI website. The GDP, export and foreign exchange reserve are used to represent economic growth. It is believed that, the selected macroeconomic variables, among others, represent the state of the economy.

To conclude, the analysis revealed that the Foreign Direct Investment (FDI) formed significant long-run relationship with three macroeconomic variables tested. The Johansen's co-integration test suggests that the FDI has been co-integrated with the macroeconomic variables. It is observed that in the long-run, the FDI is positively related to gross domestic product and foreign exchange reserve. The export is found to be negatively related to foreign direct investment. The exports are not turning out to be the significant determinant of FDI.

The findings from Granger causality based on the VECM indicate that foreign direct investment causes GDP. FDI causes GDP in both long run and short-run. While there is no bidirectional causality exists between any variables under study. Furthermore, it is observed form the findings of VECM and Granger Causality test that FDI creates a long run relationship with GDP, export and foreign exchange reserve but in short run no causality found between FDI, export and foreign exchange reserves. 
14 |FOCUS: Journal of International Business, Volume 2, Issue 2

The present study confirms the beliefs that FDI and economic growth continue to create long run equilibrium relationship. However, the limitations of the study should not be over looked. The present study is limited to only three selected macroeconomic variables. Inclusion of more variables with a longer time period may improve the results.

\section{References}

Balasubramanayam, V. N., Salisu, M., \& Spasford, M. (1996). Foreign Direct investment and growth in EP and IS Countries. Economic Journal, 106: 92-105.

Barro, R. J., \& Sala-I-Martin, X. (1995). Economic Growth. Cambridge: MA: NBER.

Bende-Nabende, A., \& Ford, J. L. (1998). FDI, policy adjustments and endogenous growth: Multiplier effects from a small dynamic model for Taiwan. World Development Report, 26 (7): 1315-1330.

Blomstrom, M., Lipsey, R., \& Zegan, M. (1994). What explains developing country growth? National Bureau for Economic Research, NBER Working Paper No. 4132.

Blomstrom, M., Lipsey, R., \& Zejan, M. (1996). Is fixed investment the key to economic growth? The Quarterly Journal of Economics, 111 (1): 269-276.

Borensztein, E., De Gregorio, J., \& Lee, J. W. (1998). How does foreign direct investment affect economic growth? Journal of International Economics , 45, 115-135.

Braunstein, E., \& Epstein, G. (2002). Bargaining power and foreign direct investment in China: Can 1.3 billions consumers tame the multinationals? Center for Economic Policy Analysis Working Paper, 13.

Brooks, C. (2002). Introductory Econometrics for Finance (2nd ed.). Cambridge University Press.

Camurdan, B., \& Ismail, C. (2009). The economical determinants of foreign direct investment (fdi) in developing countries and transition economies. e-Journal of New World Sciences Academy , 4 (3), Article Number: 3C0015. 
Caves, R. (1974). Multinational firms, competition and productivity in the host country. Economica, 41, 176-193.

Chenery, H., \& Strout, W. (1966). Foreign assistance and economic development. American Economic Review , 66, 679-733.

DeMello, L. R. (1999). Foreign direct investment led growth: Evidence from time series and panel data. Oxford Economic Papers , 51 (1), 133-151.

Dickey, D. A., \& Fuller, W. A. (1979). Distribution of the estimators for autoregressive time series with a unit root. Journal of American Statistical Association , 74 (366), 427431.

Dickey, D. A., \& Fuller, W. A. (1981). Likelihood ratio statistics for autoregressive time series with a unit root. Econometrica: Journal of the Econometric Society , 49 (4), 10571072 .

Drabek, Z., \& Payne, W. (1999). The impact of transparency on foreign direct investment. Staff Working Paper: EAR, pp. 99-102.

Dunning, J. H. (1993). Multinational Enterprises and the Global Economy. Workingham: Addison-Wesley.

Durham, B. J. (2004). Absorptive capacity and the effects of foreign direct investment and equity foreign portfolio investment on economic growth. European Economic Review , 48 (2), 285-306.

Enders, W. (2004). Applied Econometric Time Series (2nd ed.). Wiley Series in Probability and Statistics.

Enderwick, P. (2005). Attracting desirable FDI: Theory and evidence. Transnational Corporations , 14 (2), 93-119.

Engel, R. F., \& Granger, W. J. (1987). Co-integration and error correction: Representation,estimation, and testing. Econometrica , 55 (2), 251-276. 
16 | FOCUS: Journal of International Business, Volume 2, Issue 2

Fry, M. J. (1993). The Impact of FDI on Macroeconomic Growth Performance. Singapore: Institute of Asian Studies.

Griffin, K. B. (1970). Foreign capital, domestic savings and development. Oxford Bulletin of Economics and Statistics , 32, 99-112.

Grossman, G., \& Helpman, E. (1995). Technology and Trade. (G. M. Grossman, \& R. Kenneth, Eds.) Handbook of International Economics , 3.

Hosein, E., Noorbakhsh, F., Paloni, A., \& Azemar, C. (2009). The causal relationships between Foreign Direct Investment (FDI), Domestic Investment (DI) and Economic Growth (GDP) in North African non-oil producing countries: Empirical evidence from cointegration analysis. Advances In Management , 2 (11).

Johansen, S. (1991). Estimation and hypothesis testing of cointegration vector in gaussian vector autoregressive models. Econometrica , 59, 1551-1581.

Johansen, S., \& Juselius, K. (1990). Maximum likelihood estimation and inference on cointegration with application to the demand for money. Oxford Bulletin of Economics and Statistics, 52 (2), 169-210.

Klein, M., Aaron, C., \& Hadjimichael, B. (2001). Foreign direct investment and poverty reduction. Policy Research Working Paper by The World Bank, Paper No. 2613.

Kobrinm, S. J., \& Xun, W. (2005). The Liberalization of FDI Policy in Developing Countries. Pennsylvania: Department of Management, The Wharton School, University of Pennsylvania.

Levis, S. (1979). Does political instability in developing countries affect foreign direct investment flows? An empirical examination. Management International Review (19), pp. 59-68.

Lipsey, R. (1999). The Location and Characteristics of US. National Bureau for Economic Research, Working Paper No 6876. 
Marr, A. (1997). Foreign Direct Investment Flows to Low-Income Countries: A Review of the Evidence. Overseas Development Institute.

Nair-Reichert, U., \& Weinhold, D. (2001). Causality Tests for Cross-Country Panels: A New Look at FDI and Economic Growth in Developing Countries. Oxford Bulletin of Economics and Statistics, 62 (2): 153-171.

Romer, P. (1986). Increasing Returns and Long-Run Growth. Journal of Political Economy, 97: 1002-1037.

Rosenstein-Rodan, P. N. (1961). International Aid for Underdeveloped Countries. Review of Economics and Statistics , 43: 107-148.

Roy, A. G., Van, H. F., \& Berg, d. (2006). Foreign Direct Investment and Economic Growth: A Time-Series Approach. Global Economy Journal, 6 (1), Article 7.

Sala-I-Martin, X. X. (1996). The Classical Approach to Convergence Analysis. Economic Journal , 106: 1019-1036.

Santiago, C. E. (1987). The Impact of Foreign Direct Investment on Export Structure and Employment Generation. World Development Report , 3 (15): 317-328.

Schneider, F., \& Frey, B. S. (1985). Economic and Political Determinant of Foreign Direct Investment. World Development Report , 2 (13): 161-175.

Shaukat, A., \& Guo, W. (2005). Determinants of FDI in China. Journal of Global Business and Technology, 1(2): 1-13.

Singer, H. W. (1950). The Distribution of Gains between Investing and Borrowing Countries. American Economic Review , 40: 478.

UNCTAD. (2003). World Investment Report. Newyork and Geneva: UNCTAD.

Wang, M. (2002). Manufacturing FDI and Economic Growth: Evidence from Asian Economies. Department of Economics, University of Oregon Mimeo.

$\mathrm{Xu}$, B. (2000). Multinational Enterprises, Technology Diffusion and Host Country Productivity Growth. Journal of Development Economics , 62: 477-493. 